\title{
Suriye Savaşının Yermuk Filistin Mülteci Kampı Üzerindeki Etkileri
}

\author{
Selim Sezer*
}

\section{$\ddot{O} \mathbf{z}$}

$\mathrm{Bu}$ makalede 2011 yılında başlayan Suriye savaşının başkent Şam'ın dış kısımlarında bulunan Yermuk isimli Filistin mülteci kampı üzerindeki etkileri ele alınmaktadır. 1957 yılında kurulan ve Suriye'deki Filistin mülteci kamplarının en büyügü̈ olan Yermuk'ta 2012 yılından itibaren iç bölünme ve çatı̧̧malar başlamış, muhalif grupların kontrolüne geçmesi sonrasında kamp hükümet/rejim güçleri tarafindan kuşatma altına alınmış, 2015 yllında IŞiD kontrolüne geçmiştir. 2018 yılında Şam periferisine düzenlenen operasyonlar dizisi kapsamında ise Yermuk kampında da hükümet/rejim güçlerinin kontrolü sağlanmıştır. Makalede, bir arka plan ve karşılaştırma zemini olarak 1948'den 2011'e kadar olan dönemde Filistinli mültecilerin kendilerini içinde buldukları çatışmalar ve sosyal-siyasi koşullar kısaca irdelendikten sonra, 2012'den itibaren Yermuk'ta yaşanan süreçler kronolojik açıdan incelenmekte, süreçlere ilişkin farklı tarafların yorumları değerlendirilmekte ve kampta yaşanan süreçlerin hem Suriye savaşının yaşandığı diğer bölgelerdeki süreçlerle, hem de 2011 öncesindeki diğer bölgesel çatışma örnekleriyle benzer ve farklı yanları tartışılmaktadır.

Anahtar Kelimeler: Suriye, Filistin, Mülteciler, Yermuk, UNRWA

Dr. Öğr. Üyesi, İstanbul Gedik Üniversitesi, Uluslararası İlişkiler Bölümü, orcid.org/ 0000-0001-7880-8614, selim.sezer@gedik.edu.tr 


\title{
Effects of the Syrian War on the Yarmouk Palestinian Refugee Camp
}

\author{
Selim Sezer*
}

\begin{abstract}
In this article, we elaborate the effects of the Syrian war, which started in 2011, on the Palestinian refugee camp, called Yarmouk, which is located in the outskirts of the capital city Damascus. Founded in 1957, the Yarmouk camp, which is the largest among the Palestinian refugee camps in Syria, witnessed internal divisions and conflicts in 2012 and was put under siege by the government/regime forces after being captured by opposition forces. It was then captured by ISIS in 2015 and finally recaptured by government/regime forces in 2018 as part of a series of operations over the periphery of Damascus. In this article, first we briefly elaborate the conflicts and social and political conditions in which Palestinian refugees found themselves from 1948 to 2011 as a background and a basis for comparison. This is followed by a chronological examination of the processes experienced in Yarmouk starting from 2012, and the evaluation of the comments of different sides concerning these incidents. Finally, we discuss similarities and differences between the processes experienced in Yarmouk camp and the ones in other regions that the Syrian war affected, as well as the other cases of regional conflicts experienced before 2011.
\end{abstract}

Keywords: Syria, Palestine, Refugees, Yarmouk, UNRWA

* Assist. Prof., Istanbul Gedik University, Department of International Relations, orcid. org/0000-0001-7880-8614, selim.sezer@gedik.edu.tr 
“Çatışmalar başlayıp, savaş Filistinli mültecilerin on yıllardır içinde yaşadı̆̆ mahallelerden bazılarını içine aldı̆̆ında, bu mülteciler, yer değiştirme ve mülksüzleşme travmasını yaşayan yeni bir Filistinliler kuşağı haline geldi. Genç Filistinli mülteciler şimdi, ailelerinin 1948 ve 1967 hikayelerine, yakınlarını, arkadaşlarını, mahallelerini, evlerini ve geçimliklerini kaybetmelerine ilişkin kendi dramatik anlatılarını ekleyecekti.

2011 yllında Yermuk'ta yaşayan 160 bin Filistinli mülteci içinden, 2018 yllında kampın kontrolü için yürütülen savaşın son aylarında halen orada olanlar yalnızca sekiz bin kadardt. Filistinli mülteciler, bir zamanlar inşa ettikleri şeyden o denli gururluydular ve artık orada olmayan şeyler onlart o denli etkilemişti ki, Yermuk'tan 'küçük Filistin'imiz' diye bahsedeceklerdi." (Pierre Krahenbühl, UNRWA Genel Komiseri) ${ }^{1}$

\section{Giriş}

14 Mayıs 2019 Salı akşamı, Halep'in on üç kilometre doğusunda bulunan Neyrab Filistin mülteci kampı, dışarıdan gelen roket saldırılarının hedefi oldu. Birleşmiş Milletler Yakındoğu Filistin Mültecilerine Yardım Ajansı (UNRWA) tarafindan iki gün sonra yapılan açıklamaya göre, roket saldırısı kampta yaşayan ailelerin iftar için bir araya geldiği esnada gerçekleşmiş ve dördü çocuk olmak üzere on Filistinli sivil hayatını kaybetmişti. Kuruluş tarafından yapılan yazılı açıklamada, bölgedeki gerilimin son dönemde giderek arttığ1 vurgulanıyordu. ${ }^{2}$

Roket saldırısının gerçekleştiği tarih, Ramazan ayına tekabül etmesi d1şında iki başka sebepten ötürü de dikkat çekiciydi. Birinci olarak, sekiz yıllık Suriye savaşının az sayıdaki bölge dışında bitmeye yaklaşıyor gibi göründüğü bir dönemde ve Halep çatışmalarının son bulmasından yaklaşık üç yıl sonra gerçekleşmişti. İkinci olarak saldırı, sembolik bir tesadüf ürünü de olsa, 14 Mayıs'1 15 Mayıs'a bağlayan akşam yaşanmıştı: Ertesi gün, Ortadoğu genelindeki Filistin mülteci kamplarında yaşayan yüzbinlerce Filistinli, 14 Mayıs 1948'de İsrail devletinin ilan edilmesinden bir gün

1 Pierre Krahenbühl, "Palestine Refugees in Syria: A Tale of Devastation and Courage," UNRWA, 14 Mart 2019, https://reliefweb.int/report/syrian-arab-republic/palestinerefugees-syria-tale-devastation-and-courage, Son erişim: 24 Mayıs 2019.

2 "UNRWA Condemns the Killing of 10 Civilians in the Palestine Refugee Camp of Neirab in Aleppo," UNRWA, 16 May1s 2019, https://reliefweb.int/report/syrian-arabrepublic/unrwa-condemns-killing-10-civilians-palestine-refugee-camp-neirab-aleppo, Son erişim: 16 Mayıs 2019. 
sonra başlayan ve Nakba (Felaket) olarak adlandırdıkları kitlesel göç ettirme, topraksızlaştırma ve mülksüzleştirme sürecini yürüyüş ve etkinliklerle anacak ve geri dönüş taleplerini dillendirecekti. Ne var ki, bir çatışmanın sonucunda yerlerinden edilmiş olan Filistinliler, bu sürecin başlangıcının yıldönümünde, misafir oldukları bir ülkedeki bir çatışmanın yıkıcı etkisini bir kez daha yaşamıştı.

Neyrab'daki roket saldırısı Suriye'de yaşayan Filistinli mültecilerin ülkedeki savaştan etkilenmesinin ilk örneği olmadığı gibi, savaşın şu ya da bu şekilde içine aldığı tek Filistin mülteci kampı da Neyrab değildi. Nitekim ülkede bulunan Filistin kamplarından yedisi çatışmanın etkilerini somut olarak yaşamış ve bu kamplarda yaşayan Filistinlilerden bazıları için ikinci sürgün hayatı başlamıştı. Bu süreçlerin belki de en şiddetli şekilde yaşandığ1 yer ise, Suriye'deki Filistin mülteci kamplarının en büyüğü olan Yermuk kampıydı. Savaştan önce yüz binden fazla Filistinli mülteciye ev sahipliği yapan ve önemli bir siyasi merkez olan Yermuk kampı, özellikle konumu nedeniyle Suriye'deki savaşın etkilerini çok yoğun şekilde yaşadı ve beş buçuk yıl boyunca devam eden, ağır insani sonuçlar üreten süreçlere tanıklık etti.

Bu makalede Suriye savaşının Yermuk mülteci kampı üzerindeki etkileri birkaç farklı yönden incelenecektir. İlk olarak bir arka plan sunmak amacryla İsrail'in kuruluşuyla birlikte ortaya çıkan Filistinli mülteciler sorunundan ve Filistinlilerin gittikleri ülkelerde yaşadıkları diğer çatışmalı süreçlerden söz edilecek, ardından Filistinli mültecilerin Suriye'deki durumu ve Yermuk kampının gelişimi hakkında bazı temel bilgiler verilecektir. Makalenin odak noktası 2012 sonundan itibaren kampta yaşanan çatışma süreçleri olduğundan bu kısımların görece kısa tutulması ve genel bir çerçeveyle sınırlı kalınması tercih edilmiş, özellikle ilk kısım için bazı ikincil kaynakların kullanımıyla yetinilmiş, kampın genel özelliklerinin anlatıld1ğ kısımda ise ikincil kaynakların yanı sıra çeşitli rapor ve resmi istatistiklerden de yararlanılmıştır.

Sözü edilen arka planın ardından, 2012 sonlarından itibaren Yermuk kampında başlayan çatışmalar ve kuşatma süreci irdelenecek, yakın tarihli haber ve analizler temelinde oluşturulan olay örüntüsüne ilave olarak, çatışmalı sürecin gelişiminin sebeplerine dair muhtelif anlatı ve yorumlar da karşılaştırmalı olarak incelenecektir. Bunun akabinde, Nisan 2015'te IŞiD örgütünün kampa saldırması ve kampın kontrolünü ele almasıyla başla- 
yıp, tam üç yıl sonra kampın yeniden hükümet/rejim güçlerinin kontrolüne geçmesiyle sonlanan ikinci evre ele alınacaktır. Sonuç kısmında ise eldeki tüm verilerle nihai bir değerlendirme yapılırken, Yermuk'ta yaşanmış süreçlerin başka çatışmalı süreçlerle olan benzerlikleri ve özgünlükleri hakkında bazı genel değerlendirmeler de sunulacaktır. Nitekim makalenin temel amacı, Yermuk çatışmalarının tam olarak hangi dinamiklerin ürünü olduğunu ortaya çıkarmak ve farklı bakış açılarını karşılaştırmak olsa da, yan sorunsal olarak bu sürecin temel nitelikleri itibariyle özgün ve atipik olup olmadığı, yahut hangi yönlerden özgün kabul edilebileceği sorusuna da yanıt aranmaktadır. Tam da bu sebeple, ilk olarak aşağıda, bir karşılaştırma öğesi olarak 2011 öncesindeki dönemde bölge ülkelerinde yaşayan Filistinli mültecilerin kendilerini içinde bulduğu diğer çatışmalara özet halinde değinilecektir.

\section{1948 ve Sonrasındaki Çatışma Süreçlerinde Filistinli Mülteciler}

Bilindiği üzere Birinci Dünya Savaşı bitiminde, bu tarihi önceleyen dört yüzyıl boyunca Osmanlı İmparatorluğu toprağı olan Arap nüfus çoğunluklu bölgelerin önemli bir kısmında Britanya veya Fransa hakimiyeti kurulmuş, 1920 tarihli San Remo konferansı sonrasında ise, kısmen 1916 tarihli Sykes-Picot Anlaşması'na paralel olarak Suriye ve Lübnan'da Fransa mandas1, Irak, Ürdün ve Filistin'de ise Britanya mandası rejimleri tesis edilmişti. Filistin'de kurulan Britanya mandası rejimi, diğer dört ülkedeki manda yönetimlerinden en az iki yönden farklılaşıyordu. Birinci olarak burada demografik yapı önemli ölçüde değiştirilmiş, 1917 tarihli Balfour Deklarasyonu doğrultusunda, Britanya yönetiminin himayesi ve desteğiyle Filistin'e kitlesel Yahudi/Siyonist göçleri gerçekleşmiş, yahut daha doğru bir ifadeyle, 19. yüzyılın sonlarından itibaren hâlihazırda başlamış olan göçler 1920'lerin başlarından itibaren hızlandırılmıştı. İkinci önemli farklılık noktası olarak, İkinci Dünya Savaşı'nın bitimine doğru başlayan ve savaş sonrasında hızlanarak devam eden dekolonizasyon süreci kapsamında Lübnan, Suriye, Ürdün ve Filistin üzerindeki manda yönetimleri kısa aralıklarla son bulurken ${ }^{3 *}$ diğer üç örnekten farklı olarak Filistin'de etkin yerli yönetim mekanizmaları kurulmamış, dolayısıyla hiçbir formel iktidar

İstisnai olarak, Irak'taki Britanya mandası çok daha eski bir tarihte, 1932 yılında sona ermiştir. 
transferinin gerçekleşmesi mümkün olmamıştı. 1940'lı yılların özellikle ikinci yarısında Filistin'den çıkmanın yollarını arayan ve en sonunda 1947 senesinde Birleşmiş Milletler'den Filistin'i Arap devleti ve Yahudi devleti şeklinde ikiye ayıran Taksim Planı'nın geçmesini sağlayan Britanya hükümeti, bu planın hayata geçirilmesini sağlayacak kurum ve mekanizmaları dahi tesis etmedi. 14 Mayıs 1948 günü Filistin'de kalan son İngiliz komiseri Alan Cunningham, Hayfa limanından bir gemiye binerek ülkeden ayrıld1. Birkaç saat sonra Siyonist hareketin liderlerinden David ben Gurion, İsrail devletinin kurulduğunu ilan etti. İsrail devleti, ABD ve SSCB tarafindan hemen tanındi. ${ }^{4}$

Kendi bağımsızlıklarını da yeni kazanmış olan Arap devletleri, yeni kurulan İsrail devletini tanımadığı gibi, bu girişime ertesi gün savaşla karşılık verdi: Mısır, Suriye, Lübnan, Ürdün ve Irak’tan müteşekkil ordular, Birleşik Arap Gücü çatısı altında İsrail'in üzerinde devlet ilan ettiği bölgelere girdi. Ne var ki savaş bir dizi nedenden ötürü Arapların yenilgisiyle sonuçlanıp 6 Ocak 1949 tarihli Rodos Anlaşması'yla ateşkese varıldığında, İsrail'in sınırları BM Taksim Planı'nda öngörülenin de ötesine geçmiş, Gazze ve Batı Şeria ile (Taksim Planı'nda uluslararası yönetimde olması öngörülen) Kudüs'ün doğu kısımları hariç olmak üzere, manda dönemi Filistin'inin tamamını içine almıştı. İsrail, 1967 yılındaki Altı Gün Savaşı'nda bu bölgeleri de işgal edecek, hatta Mısır'dan Sina Yarımadası'nı, Suriye'den de Golan Tepeleri'ni alacaktı.

Birinci Arap-İsrail Savaşı'nın başladığı 15 Mayıs 1948 tarihi, aynı zamanda Filistinli yerel nüfus için kitlesel bir göçün başladığı tarihti. İsrail yanlısı anlatılarda bu göç, Arap devletlerinin başlattığı iki taraflı bir savaşın sonucu olarak betimlense de, gerçekte bunun planlı bir etnik temizlik süreci olduğunun göstergeleri mevcuttur. Bu yöndeki en ciddi göstergelerden biri, Kudüs'ün dış kısımlarında yer alan Deyr Yasin köyünün Siyonist milis grupları tarafindan 9 Nisan 1948 tarihinde, yani İsrail'in devlet ilanından ve Arap-İsrail savaşının patlak vermesinden önce yok edilmesi ve köy nüfusunun neredeyse tamamının öldürülmesidir. ${ }^{5}$ Deyr Yasin'de yaşa-

William L. Cleveland, A History of the Modern Middle East, Üçüncü Bask1 (Colorado ve Oxford: Westview Press, 2004), 266-267.

5 Mark Tessler, A History of the Israeli-Palestinian Conflict, İkinci Bask1 (Bloomington ve Indianapolis: Indiana University Press, 2009), 291. 
nanlar Filistinli Arap nüfus arasında büyük bir korku ve paniğe yol açmış, Ben Gurion'un devlet ilanından bir gün sonra, 15 Mayıs 1948 tarihinde Filistin'in birçok bölgesinde yaşayan yerli halk kimi örneklerde bu travmanın etkisiyle kaçmış ${ }^{6}$, kimi örneklerde ise artık İsrail Ordusu'na dönüşmüş eski milis grupları tarafından yerinden edilmişti. Nakba olarak adlandırılan bu süreçte dört yüz civarında Filistin köyünün haritadan silinmesine ilave olarak yirmi kadar yerde toplu öldürme vakaları da yaşanmış, yılsonuna kadar bölgedeki diğer Arap ülkelerine sığınan Filistinli mültecilerin sayısı 750 bini bulmuştu. ${ }^{7}$

1948 sonrasında yerlerinden edilen Filistinli mültecilerin bir kısmı İsrail kontrolü dışında kalan Gazze ve Batı Şeria'ya giderken, önemli bir kısmı da Suriye, Lübnan ve Ürdün'e sığındı. Her üç ülkede de 1940'lı yılların sonlarından itibaren çok sayıda mülteci kampı kuruldu. Birleşmiş Milletler Güvenlik Konseyi'nin Aralık 1948'de oybirliğiyle kabul ettiği 194 say111 karar Filistinli mültecilerin geri dönüş hakkını tanıyor ve bunu teşvik ediyordu; ${ }^{8}$ dünya kamuoyunun da beklentisi, bu kişilerin yakın zamanda ülkelerine geri dönmesi yönündeydi. Ne var ki takip eden y1llar ve on y1llar içinde bu geri dönüş gerçekleşmediği gibi, hem yeni çatışmaların sonu-

6 Mark Tessler, A History of the Israeli, 292-293. Tessler, o dönem İrgun örgütünün lideri olan ve gelecekte İsrail Başbakanı da olacak olan Menahem Begin'in ağzından, örneğin Siyonist milisler Hayfa'ya girdiği zaman şehirde yaşayan Arapların panik içinde ve "Deyr Yasin" diye bağırarak kaçtığını da aktarmaktadır.

7 Nakba süreci ve yarattığı sonuçlar, bugüne kadar farklı ölçeklerdeki oldukça fazla sayıda çalışmanın konusunu oluşturmuş, genel olarak bölge tarihine ilişkin çalışmalarda da şu ya da bu düzeyde bahis konusu yapılmıştır. Yazar, yukarıda alıntı yapılan Tessler'ın çalışması gibi temel referans kaynaklarının yanında özellikle, Nakba sürecinin kendisiyle birlikte, bu sürecin ikinci ve üçüncü nesil Filistinli mülteciler açısından taşıdığ 1 anlamı ve Filistin toplumu ve siyaseti içindeki çeşitli kesimlerin bakış açılarını aktaran ve "içeriden" sunulmuş bir yüksek lisans tezini önermektedir; bkz. Zarefa Akram Ali, A Narration Without an End: Palestine and the Continuning Nakba, Yüksek Lisans Tezi, Birzeit Üniversitesi (Danışman: Dr. Rana Barakat), 2012.

8 Temel olarak savaşın ve Arap-İsrail çatışmasının sonlandırılmasına ilişkin olan kararın on birinci maddesinde şu ibareler yer almaktadır: "Evlerine geri dönmek ve komşularıyla barış içinde yaşamak isteyen mültecilerin bunu öngörülebilir en erken tarihte yapmasına izin verilmeli, geri dönmemeyi seçenlerin mülkleri için ve ayrıca uluslararası hukuk ilkeleri yahut hakkaniyet gereği sorumlu hükümetler veya otoriteler tarafından tazmin edilmesi gereken mülkiyet kayıpları veya zararlar için tazminat ödenmelidir." BMGK 194 (III) sayılı kararı; İngilizce ve Fransızca karar metnine çevrimiçi erişim için bkz. https://www.securitycouncilreport.org/un-documents/ document/ip-ares-194.php 
cunda, hem de yeni kuşakların dünyaya gelmesi sonucunda Filistinli mülteci nüfusu sürekli olarak arttı ve 21. yüzyılda beş milyon düzeyine ulaşt1. ${ }^{9}$

Filistinliler, sığındıkları Arap ülkelerinde de kendilerini çeşitli çatışmaların içinde buldu ve birçok kez yer değiştirmek zorunda kaldı. "Arapİsrail çatışmasına" ilave olarak Araplar arası çatışmalar da Filistinlilerin trajedisini ağırlaştırdı. Bunlardan ilki Ürdün'de yaşanan ve temel olarak, Filistinlilerin en önemli askeri örgütlenmesi ve o dönemin çatı yapılanması olan Filistin Kurtuluş Örgütü'nü (FKÖ) hedef alan 1970 tarihli Kara Eylül vakası oldu. Ülkelerindeki aşırı kalabalık Filistinli nüfusun kendi otoritesini sarsmasından endişe eden Ürdün yönetimi, kendi topraklarının FKÖ tarafından İsrail'e karşı düzenlenen operasyonlarda bir üs olarak kullanılmasından da son derece rahatsızdı ve bu rahatsızlık, FKÖ'nün İsrail askeri unsurlarına ciddi zayiatlar verdirdiği 1968 tarihli Karame çarpışmaS1 sonrasında artmıştı. Haşimi krallığı, en sonunda, kendi otoritesine gölge düşürdüğüne inandığı silahlı Filistinli varlığına son vermeye karar verdi. 15 Eylül 1970 günü Ürdün ordusu, başkent Amman yakınlarındaki Filistin mülteci kamplarına yönelik yoğun bir operasyonlar dizisini başlattı. On gün sonra Filistinli milislerle Ürdün ordusu arasında ateşkese varılıncaya kadar olan süre zarfinda, aralarında sivil mültecilerin de olduğu binlerce Filistinli hayatını kaybetti. ${ }^{10}$

Kara Eylül'ün getirdiği temel sonuç, FKÖ'den geriye kalanların Ürdün'ü terk etmesi oldu. Örgütün bir sonraki tutunma noktası ise, yine yüzbinlerce Filistinli mülteciye ev sahipliği yapan Lübnan olacaktı. Ancak yalnızca beş yıl sonra, bu kez Lübnan'da yeni bir Araplar arası çatışma patlak verdi ve Ürdün'de yaşananlardan farklı olarak bu kez Filistinli sivil nüfus da doğrudan hedef tahtasına yerleşti. 13 Nisan 1975 tarihinde, on dört y1l sürecek Lübnan İç Savaşı'nın fitilini ateşleyen şey, Tel Zaatar kampına giden

9 Birleşmiş Milletler Mülteciler Yüksek Komiserliği (UNHCR) tarafından 2009 yılında çıkarılan bir yayında verilen bilgilere göre bu tarih itibariyle üç kuşaktan kayıtlı Filistinli mülteci sayısı yaklaşı 4 milyon 700 bin düzeyindeydi. Bu nüfusun yaklaşık \%42'si Ürdün'de, \%23'ü Gazze'de, \%16's1 Batı Şeria'da, \%10'u Suriye'de, \%9'u ise Lübnan'da yaşamaktaydı. Bkz. Riccardo Bocco, "UNRWA and the Palestinian Refugees: A History Within History," Refugee Survey Quarterly 28, say1 2-3 (Ocak 2009): 238.

10 William L. Cleveland, 362-363; ayrica bkz: Christian Chesnot ve Joséphine Lama, Filistinliler - 1948-1998 Fedai Nesli: Silahlı Mücadeleden Özerkliğe, çev. Sezai Arusoğlu (Ankara: Doruk Yayımcılık, 2003), 96-100. 
Filistinli işçileri taşıyan servis aracının Hıristiyan Falanjist milisler tarafindan taranması oldu. Aşırı sağcı bir ideolojiyi benimseyen Falanjistler, kendilerini Arap'tan önce Lübnanlı olarak görüyor ve Fenikeli kökenlerine vurgu yapıyorlard ${ }^{11}{ }^{11}$ Filistinlileri Lübnan'a yabancı unsurlar olarak gördükleri gibi, Fransız mandası döneminden kalma hassas mezhep dengesi sisteminin de Sünni Araplar lehine bozulmasından rahatsızlard $1 .{ }^{12} \mathrm{Bu}$ sebeple, her ne kadar başlattıkları çatışma "Lübnan İç Savaşı" olarak adlandırılsa da - ve zamanla gerçekten de Lübnan'da bulunan bütün unsurların bütün unsurlarla savaştı̆̆ 1 , modern tarihte eşine az rastlanan türden bir çok taraflı iç çatışma niteliğini alsa da - başlangıçtaki hedefi ülkedeki Filistinlilerdi. 1982 yılında İsrail'in başlattığı ve başkent Beyrut'un da kısa süre içinde düşmesine yol açan işgal ise, çatışmaya yeni bir boyut kattı. Bu iki yönlü çatışma ortamında FKÖ, 1982 yılının ağustos ayında Lübnan'dan da çıkarıldı. Hemen arkasından, 16-18 Eylül 1982 tarihlerinde, Beyrut'un dış kısımlarında yer alan ve artık savunmasız halde kalmış olan Sabra ve Şatila isimli iki Filistin mülteci kampı, Falanjist milislerin saldırısına uğradı. Üç bine yakın sivilin öldürüldüğü katliam, Filistinlilerin kolektif hafizasında neredeyse Nakba kadar büyük bir yer bulacaktı.

\section{Suriye'deki Filistinli Mülteciler ve Yermuk Kampı}

Suriye, Lübnan İç Savaşı'ndaki taraflaşmanın bir uzantısı olarak Hafız Esad yönetimi tarafindan 1982-83 yıllarından itibaren binlerce El Fetih militanının tutuklanmas ${ }^{13}$ dışarıda tutulursa, 2011 yılına kadar bu tür ça-

11 John C. Rolland (haz.), Lebanon: Current Issues and Background (New York: Nova Science Publishers, 2003), 138.

12 Osmanlı İmparatorluğu'nun son dönemlerinden itibaren Lübnan'daki siyasi kurumlarda dinsel/mezhepsel temsil sistemi uygulanmış, bu sistem Fransız mandası döneminde "Büyük Lübnan"ın kurulması sonrasında detaylı ve yerleşik hale gelmiştir. Sistemin kuruluşu, detayları ve Lübnan İç Savaşı'na giden süreçteki rolü için bkz. Pierre Vallaud, Le Liban Au Bout Du Fusil (Paris: Librairie Hachette, 1976), 45-62. Filistinliler Lübnan'da vatandaş statüsüne veya buna yakın bir statüye sahip olmadığ1 için örneğin parlamentoda temsil oranları gibi konularda Filistinli varlığının somut bir etkisi olmasa da, genel olarak ülkedeki demografik yapının değişimi iç savaşın önemli sebepleri arasında kabul edilmektedir.

13 Nidal Bitar, "Yarmouk Refugee Camp and the Syrian Uprising: A View from within," Journal of Palestine Studies 43, say1 1 (Güz 2013): 63. Lübnan İç Savaşı'na müdahil olan dönemin Suriye yönetimi, çeşitli nedenlerden ötürü burada bulunan FKÖ unsurlarıyla da çatışmaya girmişti. Bazı yorumlarda bunun sebebi, Hafız Esad'ın Filistinli grupların kendi kontrolü altında olmasını istemesi ve bunun aksi bir durum 
tışmalardan uzak kalmasının yanı sıra, en başından beri Filistinli mültecilerin görece en elverişli koşullarda yaşadığı Arap nüfus çoğunluklu ülke oldu. 1949 yılında, dönemin Suriye Başbakanı Hüsnü el-Zaim, Batı'dan gelecek ve kalkınma projelerinde kullanılacak finansal yardım karşılığında azami 300 bin Filistinli mülteciyi ülkelerine kabul etmeye istekli olduklarını duyurmuştu. ${ }^{14}$ Suriye devleti o y1l içerisinde yaklaş1k 95 bin Filistinli mülteciyi kaydetti. Bu kişilerin çoğu, (1948 öncesindeki) Filistin'in kuzey bölgelerinden geliyordu: Safed kökenliler en büyük topluluğu oluştururken, bunu Taberiye, Hayfa, Akka, Nasıra ve Yafa kökenliler izliyordu. 1967 yılındaki Altı Gün Savaşı sonrasında yeni bir mülteci dalgası oluşuğu gibi, Ürdün'deki Kara Eylül, İsrail'in Lübnan işgali ve ABD'nin Irak işgali sonrasında da daha önce bu Arap ülkelerine yerleşmiş olan Filistinlilerden bazıları Suriye'ye göç etti. ${ }^{15}$

1949 y1lında ülke içinde, UNRWA'yla koordinasyon içinde çalışacak ve mültecileri kayıt altına alacak, ihtiyaç duyulan yardımları sağlayacak ve onlar için uygun işler bulacak olan, Filistin Arap Mülteci Kurumu isimli bir teşkilat kuruldu. Aynı yıl Suriye hükümeti, Filistinli mültecilere Suriye vatandaşlarıyla neredeyse eşit haklar sunan çeşitli yasalar çıkarmaya başladı. Filistinliler, 1952 tarihli bir yasayla, Suriye vatandaşı olmayanlara yönelik çeşitli mesleki kısıtlamalardan da muaf tutuldu. 1956 yılında çıarılan 260 sayılı yasayla ise Suriye'de yaşayan Filistinli mültecilerin Suriyeli olarak kabul edildiği ve kendi Filistin vatandaşlıklarını korumakla birlikte, iktisadi ve ticari faaliyetler dâhil pek çok konuda Suriye vatandaşlarıyla aynı haklara sahip oldukları hüküm altına alındı. ${ }^{16}$

Zaman zaman Filistinlilerin Suriye'de sahip oldukları haklar Baas rejiminin tercihleriyle ilişkilendirilse de, zikredilen tarihlerden de anlaşılacağ1 üzere, bu rejimin kurulduğu 1963 y1lından önce bu haklar hâlihazırda önemli ölçüde tesis edilmişti. Baas rejimi de aynı yönelimi sürdürürken, 1964 y1lında Suriye'de yaşayan Filistinlilerden müteşekkil Filistin Kur-

meydana geldiği için müdahale etmesi olarak gösterilmektedir. Örneğin bkz. Anaheed al-Hardan, "The Right of Return in Syria: Building a Culture of Return, Mobilizing Memories for the Return," Journal of Palestine Studies 41, say1 2 (Kış 2012): 67.

14 Laurie Brand, "Palestinians in Syria: The Politics of Integration," Middle East Journal, 42, say1 4 (Kış 1988): 622.

15 Al-Hardan, The Right of Return in Syria...," 63-64.

16 Laurie Brand, "Palestinians in Syria...," 623. 
tuluş Ordusu'nu kurma ve mültecilere burada askerlik imkânı sunma gibi yeni açılımlar da getirdi. ${ }^{17}$ Bir başka deyişle Suriye'deki Filistinli mülteciler, özellikle yüzden fazla meslek grubunda çalışmalarının ve mülteci kamplarındaki barınaklarında herhangi bir tadilat yapmalarının bile yasak olduğu Lübnan gibi ülkelerden farklı olarak, seçme ve seçilme hakkı d1şında, Suriye vatandaşlarının sahip olduğu neredeyse tüm haklara sahip olmuş oldu. Ayrıca, Suriyeliler ve ülkede yaşayan Filistinliler arasında, iş, eğitim ve evlilik bağları yoluyla, Arap dünyasında benzeri görülmeyen düzeyde bir entegrasyonun gerçekleşmesi mümkün oldu. ${ }^{18}$

Suriye'de 1948'i izleyen dönemde Birleşmiş Milletler'in idaresi altında sekiz Filistin mülteci kampı kurulurken, bu sayı zamanla on ikiye yükseldi. UNRWA tarafından yapılan tasnife göre bu on iki kamptan Deraa, Hama, Humus, Ceramana, Han Dunun, Han Eşiye, Neyrab, Kabr Esit ve Sbeyne kampları resmi kamp statüsündeyken, Ayn el-Tal, Lazkiye ve Yermuk kampları "gayriresmi kamp" statüsündedir. Gayriresmi kamp, "zaman içinde evsahibi hükümetler tarafindan Filistinli mültecilere barınma sağlamak için kurulmuş kamp" şeklinde tanımlanırken, UNRWA'nın bu "gayriresmi kamplara" katı atık toplama dışında resmi kamplarla aynı hizmetleri sundukları belirtilmektedir. ${ }^{19}$

Suriye Arap Cumhuriyeti tarafindan verilen resmi rakamlarda, 31 Aralık 2011 tarihi itibariyle ülkede yaşayan toplam Filistinli mülteci sayısı 496 bin olarak gösterilirken, kamplara göre bir tasnif yapılmaksızın Şam'da yaşayan Filistinli mültecilerin sayısının 341 bin olduğu söylenmektedir. 2012 yılı sonuna ilişkin rakamlar sırasıyla 502 bin ve 346 bin olarak verilirken, söz konusu istatistiklerde yıldan yıla artışın devam ettiği, son yayınlanan veri olan 2016 sonu istatistiklerinde Suriye geneli için 518 bin, Şam için 358 bin rakamlarının verildiği görülmektedir. ${ }^{20}$ UNRWA verilerinde

17 Brand, "Palestinians in Syria...," 624. Öte yandan, Suriye'deki Baas yönetiminin Filistinli askeri grupları da himaye etmesi, eğitim ve silah desteği vermesi ve özellikle ideolojik olarak kendisini Filistin davasının destekleyicisi olarak tanımlaması, bu yönetimi hem Baas öncesi Suriye yönetiminden, hem de Ürdün ve Lübnan yönetimlerinden farklılaştırmaktadır.

18 Nidal Bitar, "Yarmouk Refugee Camp..., " 62.

19 UNRWA, "Where We Work-Syria," https://www.unrwa.org/where-we-work/syria, Son erişim: 19 Eylül 2019.

20 Suriye Arap Cumhuriyeti Merkezi İstatistik Bürosu, http://cbssyr.sy/yearbook/2012/ Data-Chapter2/TAB-12-2-2012.pdf, http://cbssyr.sy/yearbook/2013/Data-Chapter2/TAB12-2-2013.pdf, http://cbssyr.sy/yearbook/2017/Data-Chapter2/TAB-14-2-2017.pdf, Son erişim: 19 Eylül 2019. 
ise 2018 y1lı itibariyle Suriye'de kay1tlı Filistinli mülteci say1s1 552 bin olarak belirtilmekte, ancak aynı tarih itibariyle bunların içinden Suriye'de kalmış olanların sayısının 418 bin olduğu ifade edilmektedir. ${ }^{21} \mathrm{Bu}$ veriler ve mevcut durum bir arada değerlendirildiğinde, kayıtlı Filistinli mülteci sayısı (yeni doğumlarla birlikte) kağıt üzerinde artarken, fiili durum itibariyle Suriye'deki Filistinli mültecilerin yaklaşı beşte birinin Suriye'yi terk ettiği, başta Yermuk'takiler olmak üzere on binlerce Filistinlinin ülke içinde yer değiştirdiği, ancak resmi olarak halen aynı yerlerde kayıtlı olduklarından, çatışmaların sona ermesi ve hayatın normale dönmesiyle birlikte - geldikleri yer olan Filistin'e değilse de - kayıtlı oldukları mülteci kamplarına geri döneceklerinin varsayıldığı sonucuna ulaşmak, yahut böyle bir yorum yapmak mümkün görünmektedir.

Yermuk kampı, bu mülteci kamplarının içinde en büyük ve en kalabalık olanıydı. Başlangıçta çadırlardan oluşan Yermuk’ta bir süre sonra kalıcı binalar inşa edildi ve kamp zamanla, yakın civarlarında Suriyelilerin de yaşadığı, büyük bir semte dönüştü. ${ }^{22}$ Yermuk kampı için "Filistin diasporasının başkenti" adlandırmaları da yapılıyordu. ${ }^{23}$

1957 yılında kurulmuş olan Yermuk kampı, iki kilometre kareden büyük bir alana yayılmış olup, güneyindeki Hacerülesved bölgesiyle önemli ölçüde bütünleşmiş olan, büyük bir semte benzemektedir. UNRWA kayıtlarına göre 2011'e kadar yaklaşık 150 bin mülteciye ev sahipliği yapan kampta, çatışmaların başlamasından önce en önemli sorunlar, hava kirliliği, ev içi şiddet, yüksek oranda uyuşturucu bağımlılığı, artan oranda çocuk emeğinin kullanılması, barınakların riskli olması, yaşam maliyetlerinin gelirle orantısız olması, erken yaşta evlilik ve boşanma oranlarının yüksek olmas1, okulu erken bırakma oranlarının artması, çevresel sağlık bilincinin bulunmaması, kampın bazı bölgelerinde içilebilir su bulunmaması, yüksek işsizlik oranı ve iş olanaklarının azlığı ve son olarak, iktisadi ve psikolojik

${ }^{21}$ UNRWA, "Where We Work-Syria."

22 "Palestinian Camp Yarmouk, Back in Assad Hands, Gutted by Years of War," Times of Israel, 21 Mayis 2018, https://www.timesofisrael.com/palestinian-camp-yarmoukback-in-assad-hands-gutted-by-years-of-war/, Son erişim: 24 Mayıs 2019.

23 Maureen Clare Murphy, "Syrian government approves return to Yarmouk," Electronic Intifada, 10 Kasim 2018, https://electronicintifada.net/blogs/maureen-clare-murphy/ syrian-government-approves-return-yarmouk, Son erişim: 24 Mayıs 2019. 
baskıdan kaynaklı sağlık sorunları olarak tanımlanıyordu. ${ }^{24}$ Bununla birlikte Suriye'deki kampların bölgedeki diğer Filistin mülteci kamplarından, Yermuk'un ise Suriye'deki geri kalan kamplardan çok daha iyi durumda olduğu, genel kabul gören bir durumdu.

Dev bir pazara sahip olan önemli bir ticaret merkezi olan Yermuk, bazı özgün nitelikleri itibariyle de Suriye'deki diğer Filistin mülteci kamplarından ayriliyordu. En yoksul olanlardan daha az yoksul olanlara, tüccarlar, orta sinif meslek mensupları ve milyonerlere varıncaya kadar her sinıftan ve gelir düzeyinden insanın yaşadığı Yermuk kampı, pek çok kişinin bilinçli olarak içinde yaşamayı seçtiği bir yerdi. Kamp içinde ve dışında görev yapan sayısız doktor, avukat, mühendis, öğretmen, memur ve işadamı vardı. Aynı zamanda Suriye genelindeki Filistinlilerin, ülkedeki Filistinli yaşamının merkezi olarak gördüğü yerdi. Belirttiğimiz gibi sınırlarının dışına taşan geniş bir bölgeyi ifade eden Yermuk'ta zamanla Filistinliler azınlık konumuna dahi gelmişti, ancak "Yermuk'un kimliği her zaman belirgin bir şekilde Filistinli oldu, kamptaki siyaset ve kamusal etkinlikler Filistin'e odaklandı ve bölgenin Suriyeli sakinleri de sıklıkla 'Filistinlileşir' hale geldi." ${ }^{25}$ Ampirik verilere dayanmaksızın yapılan bir değerlendirmeye göre Yermuk kampında yaşayan Filistinlilerin "tahminen" yüzde doksanı bir Filistinli örgütün üyesi ya da destekçisiydi; en fazla üye veya destekçiye sahip olan grup El Fetih olarak tanımlanırken, onu sırasıyla Hamas, sol gruplar ve İslami Cihad izliyordu. ${ }^{26}$

Yermuk kamp1, kuruluşunu takip eden on yıllar boyunca Filistinliler için güvenli bir sı̆̆ınak olmuştu. Aynı zamanda pek çok Filistinli örgütün merkezlerine de ev sahipliği yapıyordu ve Şam merkezine oldukça yakın bir yerde olması sebebiyle, diğer kamplardan daha fazla siyasi önem taşıordu. Ancak kampın kaderi, “Arap Baharı" olarak adlandırılan siyasi altüst oluşun parças1 veya yansıması olarak Mart 2011'de Deraa'da düzenlenen gösterilerle başlayan süreçle birlikte, radikal bir şekilde değişecekti. Nitekim Suriye'deki süreç, bu makalenin konusu olmayan sebeplerden ötürü hızla askerileştiğinde ve şiddet sarmalı bütün ülkeyi içine aldığında, başkentin sınırları içinde yer alan bu mülteci kampının tüm bu siyasi süreçlerin ve şiddetin dışında kalması mümkün olmayacaktı.

24 UNRWA, "Where We Work-Syria-Yarmouk (Unofficial Camp)," https://www.unrwa. org/where-we-work/syria/yarmouk-unofficial-camp, Son erişim: 20 Eylül 2019.

25 Nidal Bitar, "Yarmouk Refugee Camp...," 63.

26 Nidal Bitar, "Yarmouk Refugee Camp..., " 63. 


\section{Yermuk'ta İlk Çatışmalar ve Kuşatma: Genel Görünüm}

Suriye çatışmasının başlangıcından itibaren bu ülkedeki Filistinli gruplar genel olarak tarafsılılı çizgisi izledi. Ancak bireysel düzeyde yönetimin ya da muhalif/isyanc1 grupların yanında yer alan Filistinli mülteciler olduğu gibi, örgüt düzeyinde de bu tarafsızlığın istisnaları oldu. Bu istisnalardan biri, sıklıkla Filistin Halk Kurtuluş Cephesi (FHKC) ile karıştırılan, gerçekte ise 1968 yılında bu oluşumdan kopmuş bir "hizip" olan, Ahmed Cibril liderliğindeki Filistin Halk Kurtuluş Cephesi-Genel Komutanlık (FHKC-GK) örgütü oldu. ${ }^{27}$ Corc Habaş liderliğindeki FHKC'den tam da ismi zikredilen örgütün Suriye'deki Baas yönetimine karşı eleştirel duruşu nedeniyle kopmuş olan ve sırtını bu yönetime dayama politikası izleyen Şam merkezli FHKC-GK, 2011 yılına kadar kesintisiz olarak sürdürdüğü Şam hükümeti destekçisi tavrını muhalif hareketlerin ortaya çıkmasından ve şiddetin bir iç savaşa dönüşmesinden sonra da devam ettirdi. Tarafsızlığın diğer istisnası ise, Hamas'ın kendisiyle organik bir bağının bulunmadığını ileri sürdüğü, ${ }^{28}$ ancak en azından taban düzeyinde Hamas'la ortaklaşan Eknaf Beytü'l-Makdis örgütüydü. Suriyeli isyanc1 gruplarla gevşek denebilecek bağlara sahip olan bu örgüt, Suriye'de yaşayan Filistinlilerin oluşturduğu yegâne rejim karşıtı oluşum oldu.

2012 yılı içinde Yermuk kampı dahilinde farklı eğilimlere sahip oluşumların güç mücadelesinin başlaması ve aynı zamanda kamp dışından gelen bazı silahlı unsurların da Yermuk'a yerleşmesi, kampta tansiyonu hızla artırd. Diğer Filistinli grupların arabuluculuk, uzlaşı ve Yermuk'un Suriye çatışmasının dışında tutulması yönündeki girişimleri de başarısız oldu ve son kertede, 2012 yılının Aralık ayı ortalarında, Eknaf Beytü'l-Makdis'in

$27 \mathrm{Bu}$ "karıştırma" haline gerek Türkçe, gerekse yabancı dildeki haber ve makalelerde sıklıkla rastlanmaktadır ve bu durumun uç örnekleri de görülebilmektedir. Örneğin bir web sitesinde, FHKC-GK Siyasi Büro üyelerinden Enver Reca ve beraberindeki birkaç kişiyle yapılan görüşmelerden hareketle hazırlanmış bir makalenin bir kısmında oluşumun tarihine yer verilirken aslında anlatılan şey, Corc Habaş'ın kurduğu ve dünyanın adını Leyla Halid ve arkadaşlarının gerçekleştirdiği uçak kaçırma eylemleriyle duyduğu FHKC'nin tarihidir. Bkz: "Syria is a Battle for Palestine," Islam Times English, t.y., https://www.islamtimes.org/en/interview/251081/syria-is-a-battlefor-palestine, Son erişim: 10 Haziran 2019. Genel sekreterliğini halen tutuklu bulunan Ahmed Saadat'ın yaptı̆ğ Filistin Halk Kurtuluş Cephesi'nin Suriye savaşındaki resmi tutumu tarafsızlık ve dış müdahale karşıtlığı olmuştur.

28 "Hamas Denies Supporting Militant Groups in Syria," Middle East Monitor, 19 Nisan 2015, https://www.middleeastmonitor.com/20150419-hamas-denies-supportingmilitant-groups-in-syria/, Son erişim: 10 Haziran 2019. 
öncülük ettiği Filistinli ve Suriyeli rejim karşıtı unsurlar kampın çoğunluğunun kontrolünü ele geçirdi. ${ }^{29}$

Yermuk kampı, on binlerce Filistinliye uzun yıllar boyunca ev sahipliği yapan bir mülteci kampı olmaktan fazlasını da ifade etmektedir. Başkent Şam'ın merkezine on kilometreden az bir mesafede yer alan kamp, aynı zamanda şehir merkezine giden güneydeki ana yollardan birinin üzerine kurulmuştur. ${ }^{30} \mathrm{Bu}$ önemli stratejik konum, kampı genel olarak Suriyeli isyancılar için son derece önemli hale getirmiştir ve bazı yorumlara göre Suriyeli muhalif gruplar Yermuk kampını Beşar Esad'ı devirme girişiminde potansiyel bir ileri üs olarak görmüştür. ${ }^{31}$

Yermuk kampı, tam da aynı nedenlerden ötürü Suriye hükümeti/rejimi ve onunla birlikte hareket eden unsurlar açısından da kritik önemdeydi. Bu sebeple Suriye ordusu, isyancı grupları etkisiz hale getirme ve kampın kontrolünü sağlama girişimlerine başlamakta gecikmedi. Ne var ki Yermuk'un uluslararası koruma altındaki bir mülteci kampı olması, doğrudan müdahaleyi zorlaştıran önemli bir faktördü. Kampın içinde isyancı unsurlara karşı kullanabileceği müttefik veya vekil güçlerin de bulunmaması (yahut kalmamas1) sebebiyle, Suriye ordusu, isyanciları teslim olmaya zorlamak için ağır insani sonuçlar üretecek bir yönteme başvurdu: Yermuk kampını mutlak bir kuşatma altına aldı.

2012 y1lının son günlerinde başlayan ve iki yıldan daha uzun süren kuşatma sürecinde, gıda ve su yetersizliği ile hastalıklar sebebiyle yüzlerce kişinin hayatını kaybettiği ifade edilmektedir. ${ }^{32} \mathrm{Bu}$ süre zarfında kampa giren

29 Mariam Karouny, "Syrian Rebels Take Control of Damascus Palestinian Camp," Reuters, 17 Aralık 2012, https://www.reuters.com/article/us-syria-crisis/syrian-rebelstake-control-of-damascus-palestinian-camp-idUSBRE8AJ1FK20121217, Son erişim: 10 Haziran 2019. Haberde, pek çok FHKC-GK üyesinin isyancıların tarafına geçtiği, Ahmed Cibril'in iki gün önce kampı terk ettiği, az sayıdaki FHKC-GK üyesinin hükümet/ rejim güçlerine katılmak üzere kampın kuzeyine çekildiği ve kamptaki çatışmaların durduğu bilgileri de verilmekteydi.

30 Raf Sanchez, "Palestinian Refugee Camp in Syria Turns 'Unimaginably Brutal' as Assad Regime Drives Isil out of Yarmouk," The Telegraph, 26 Nisan 2018, https:// www.telegraph.co.uk/news/2018/04/26/palestinian-refugee-camp-syria-turnsunimaginably-brutal-assad/, Son erişim: 17 Mayıs 2019.

31 Raf Sanchez, "Palestinian Camp Yarmouk..."

32 Louisa Loveluck, Magdy Samaan ve Ruth Sherlock, "Inside the Living Hell of Yarmouk," The Telegraph, 7 Nisan 2015, https:/www.telegraph.co.uk/news/ worldnews/islamic-state/11520845/Inside-the-living-hell-of-Yarmouk.html, Son erişim: 17 Mayıs 2019. 2013 yılının ekim ayında, Yermuk'un en büyük camisinin imamının, 
resmi bir yardım konvoyu olmamış, Birleşmiş Milletler'in gıda yardımları kampa çok uzun süre sonra girebilmiş ve gıda dağıtımını bekleyen binlerce kişinin enkaza dönmüş binaların önünde oluşturduğu son derece uzun kuyrukları gösteren fotoğraflar dünyanın gündemine yerleşmiştir. Suriye ordusu bu süreçte kuşatmanın yanında hava saldırılarına da başvurmuş ve bu saldırılar sonucunda gerek isyancılardan, gerekse kamp sakinlerinden çok sayıda kişi hayatını kaybetmiştir. Nisan 2015 itibariyle UNRWA sözcüsü Chris Gunness kamptaki durumu "gayriinsaninin ötesinde" diye tanımlarken, kuruluşun genel komiseri Pierre Krahenbühl, "tümüyle felaket" tanımlamasını kullanmıştır. ${ }^{33}$ Kampa neredeyse her türlü giriş engellenirken çıkışlara kısmen izin verilmiş, yukarıda aktarılan açıklamaların yapıldığ tarih itibariyle, kampın nüfusu 18 bin düzeyine kadar inmiştir. ${ }^{34}$

\section{Muhtelif Anlatılar}

Yermuk kampında 2012 sonundan itibaren yaşanan trajedinin sebeplerine ilişkin anlatılar birbiriyle uyumsuzdur ve bu anlatılar, kişilerin ya da tarafların Suriye savaşına ilişkin genel yorum ve pozisyonlarıyla paraleldir. Kampta yaşanmış olan süreçler şimdilik akademik literatürde sınırlı denebilecek düzeyde yer bulmuş olsa da, medya ve gündelik siyaset alanlarında uzun yıllardır tartışmaların konusu olmaktadır. Makalenin bu kısmında, bu ihtilaflı anlatılardan birkaçı seçilecektir. Ortaya konulan anlatılar temel olarak, yaşananların sorumluluğunun kime ait olduğu sorusu etrafinda dönmektedir. Bizim makalemizin böyle bir sorunsalı ve amacı olmamakla birlikte, seçili örneklerin karşılaştırmalı olarak incelenmesi, ortaya koymaya çalıştığımız tablo açısından faydalı olacaktır.

İhtilaflı ve taraf olma niteliğindeki örnekleri incelemeden önce, Yermuk'ta yaşanan süreçleri görece tarafsız bir bakış açısıyla betimlemeye çalışan iki akademik çalışmadan alıntılar yapmak yerinde olacaktır. Beyrut Amerikan Üniversitesi Sosyoloji Bölümü’nde öğretim üyesi olan Anaheed al-Hardan

hayatta kalmak için kedi, köpek ve eşek eti yemeye cevaz veren bir fetva yayınladığı da aktarılmaktadır. Bkz. Nidal Bitar, "Yarmouk Refugee Camp...," 75.

33 Ayrica bkz. "Islamic State-Controlled Yarmouk Refugee Camp Conditions 'Beyond Inhumane," The Telegraph, 7 Nisan 2015, https:/www.telegraph.co.uk/news/ worldnews/islamic-state/11519106/Islamic-State-controlled-Yarmouk-refugee-campconditions-beyond-inhumane.html, Son erişim: 17 Nisan 2019.

34 "ISIS Seizes Most of Yarmouk Refugee Camp in Damascus: PLO," Daily Star, 1 Nisan 2015, http:/www.dailystar.com.lb/News/Middle-East/2015/Apr-01/292956-isis-seizesmost-of-yarmouk-refugee-camp-in-damascus-plo.ashx, Son erişim: 27 Mayıs 2019. 
tarafindan yayınlanan bir raporda, Suriye'de Mart 2011'i izleyen dönemde yaşanan şiddet olaylarından ve bu olaylardan bazılarına Filistinlilerin de dahil olduğu iddialarından söz edilerek, Filistinlilerin iç savaş sarmalına sürüklenmesi, Yermuk'taki çatışmaları doğuran iç dinamiklerin öncesine ve dışına kadar götürülmektedir. Al-Hardan'a göre Suriye çatışmasının ilk aylarında Deraa'da ve Lazkiye kampında, yönetim karşıtı hareketlere ve kundaklama gibi eylemlere katılan Filistinlilerin olduğu ve Ahmed Cibril'in grubunun da bu kişilerle karşı karşıya geldiği iddialarının yayılması, Filistinliler arasında bazı iç ihtilaf ve gerilimleri doğurmuştu. Öte yandan, 15 Mayıs 2011 günü Nakba günü vesilesiyle, 5 Haziran 2011 günü de (Altı Gün Savaşı'nın yıldönümü olan) Naksa günü vesilesiyle Suriye yönetiminin teşvikiyle İsrail sınırına doğru mülteci yürüyüşleri gerçekleştirilmiş, her iki yürüyüşe de İsrail askerlerinin ateş açması ve can kayıplar1nın yaşanması sonrasında Yermuk'ta yaşayan bazı Filistinliler, kendilerini korumayan Suriye devletine tepki göstermiş ve kamp içinde ciddi huzursuzluklar başlamıştı. Erken tarihlerden itibaren kamp içinde rejim yanlısı ve rejim karşıtı gösteriler düzenlenirken, kaçırma, suikast ve bombalı araç saldırısı gibi şiddet eylemleri de yaşanmış ve farklı taraflar bu tür şiddet eylemlerinin hedefi olmuştu. ${ }^{35}$

2012 yılına kadar Yermuk’ta yaşayan ve Suriye Kızılayı için de çalışan Filistinli-Suriyeli gazeteci Nidal Bitar da, Journal of Palestine Studies dergisinde yayınlanan makalesinde "içeriden bir anlatı" sunarken, sürecin kökenlerini 2011 yılındaki Nakba ve Naksa günü yürüyüsslerine götürmektedir. Bitar'a göre Nakba gününde Golan Tepeleri’ne doğru yapılan yürüyüşü teşvik eden ve otobüslerle destek sağlayan Şam yönetimi, bu yürüyüşle dünyaya kendisinin Filistin destekçisi olduğu mesajını vermeye çalışıyordu, ancak teşvik edip destek verdiği yürüyüş için koruma sağlayamadığı görüşü hakimdi. O gün düzenlenen yürüyüşte hayatını kaybeden Filistinlilerin üçü de Yermuk kampındandı. Aynı durum, Naksa gününde, daha büyük çapta tekrarlanmış, on ikisi Yermuk'tan olmak üzere toplam 23 kişi hayatını kaybetmişti. O gece kampta "Gençlik Koalisyonu" tarafından düzenlenen toplantıda, sınıra gitmelerini kolaylaştıran, ancak kendilerine koruma sağlamayan rejimin kendilerini kullandığı düşüncesi ağır basmıştı.

35 Anaheed Al-Hardan, “A Year On: The Palestinians in Syria," Syrian Studies Association Bulletin 17, say1 1 (2012): 2-4. 
Hayatını kaybedenler için düzenlenen cenaze töreni sonrasında kampta yaşayan halk, kendilerine hiçbir kayda değer destek sağlamayan bütün Filistinli siyasi gruplara ve liderlerine tepkiliydi. Bu gergin ortamda FHKC-GK bürosuna da saldırı düzenlendi. FHKC-GK milislerinin saldırganları dağıtmak için ateş açması sonucunda, Rami Siyam isimli on dört yaşındaki bir genç hayatını kaybetmişti. Bazı kamp sakinleri bu durumu, FHKC-GK'nın Suriye'deki çatışma sürecine rejim lehine katılacağının göstergesi olarak yorumladı. "Gençlik Koalisyonu", düzenlediği çok sayıda toplantıdan sonra, kampın, rejimle çatışmaya girecek bir pozisyon almaması yönünde karar verdi; ancak koalisyon içindeki azınlık bir grubun talebi doğrultusunda, Suriye yönetimi tarafından aranan kişilere kampta geçici bir sığınma verilmesi kararlaştırıldı.

17 Ağustos 2011 günü Yermuk'ta ilk rejim karşıtı gösteri düzenlendi. Aynı tarih itibariyle çeşitli çatışma bölgelerinden gelip Yermuk'a sığınanlar da vardi. Sonbahar aylarında FHKC-GK lideri Ahmed Cibril, kendi grubunun kamptaki mensuplarına silah dağıtmaya başladı. Bir yıldan uzun bir zaman sonra, Aralık 2012'de ise Cibril'in grubu, kampın girişine kontrol noktaları kurup, yakınlardaki Hacerülesved ve Yelda'da isyancılarla çatışmaya başladı. Bitar'a göre bu tarih itibariyle isyancıların çatı yapılanması olan Özgür Suriye Ordusu, "Şam'a açılan kapı” olarak gördüğü Yermuk’a uzun zamandır gözünü dikmiş durumdaydı ve Yermuk'u, Şam'ı ele geçirecek hamlede bir rampa olarak gördükleri herkes tarafından ifade edilen bir gerçekti. Gerilimin çok yüksek olduğu bir anda, 16 Aralık 2012 günü Suriye ordusu, on sivilin ölümüne yol açacak şekilde Yermuk kampına savaş uçaklarıyla saldırı düzenledi ve daha sonra bunun yanlışlıkla olduğunu ileri sürdü. Ertesi gün ÖSO, müttefiki olan Nusra Cephesi'yle birlikte kampa girdi: FHKC-GK'nın direncine ve rejim güçlerinin isyancı mevzilerini vurmasına rağmen kamp isyancıların eline geçti. ${ }^{36}$

Burada kısaca aktardığımız görece tarafsız olay anlatılarının dışında, Yermuk'taki süreçleri belli bir siyasi perspektif içinden değerlendiren farklı anlatılar da mevcuttur ve aşağıda bunlardan altı tanesine yer verilecektir. Belirtildiği üzere bu anlatılar birbiriyle uyumsuzdur ve Suriye çatışmas1na dair genel tutumların yansıması ve uzantısı niteliğindedir. Örneğin, sol gelenekten gelen ve yaşamının uzun yıllarını siyasi faaliyet içinde geçiren bir isim olan Reşad Ebu Şever'e göre Yermuk kampında yaşanan çatışmalı süreç ilk olarak, kampta bulunan FHKC-GK üyelerine suikastlar düzen-

36 Nidal Bitar, “Yarmouk Refugee Camp...," 65-73. 
lenmesiyle başlamıştı. Bu suikastları düzenleyen rejim karşıtı gruplar için Yermuk iki açıdan kritik önem taşıyordu. Birinci olarak, kamp (yukarıda da belirtildiği üzere), Şam'ın stratejik bir noktasında yer alıyordu ve ele geçirilmesi, hükümetin devrilmesi kampanyasında kritik bir rol oynayacaktı. İkinci olarak rejim karşıtı unsurlar, kasten kampı çatışma alanına çevirmeyi hedeflemişlerdi. Amaçları bu şekilde Suriye Ordusu'nu harekete geçirmeye ve kampa saldırmaya zorlamaktı; bu şekilde, düzenlenecek operasyonları "medyada rejime iftira için kullanacaklar"dı. Bir başka deyişle Suriye ordusunu Filistinlilere saldırıyor gibi gösterecek ve bu şekilde siyasal propaganda faaliyeti yürütebileceklerdi.

Ebu Şever'e göre Yermuk sakinleri, Suriye savaşı başladığında, "1948 felaketinden sonra onları kucaklayan ve Arap kardeşi olarak gören Suriye halkına ve Suriye vatanına tarafsız kaldılar" ve binlerce silahlı kişinin kampı istila etme girişimleri Halk Komiteleri tarafından engellendi. Ancak rejim karşıtı gruplar 1srarcıydı. Örneğin Suriye Ulusal Koalisyonu üyelerinden Corc Sabra, El-Arabiye kanalına verdiği bir demeçte "Kamp Suriye toprağıdır. Kimse Yermuk kampına girişimizi engelleyemez. Çünkü Şam savaşını çözümleyecek olan yer burasıdır" demiş ve bu şekilde niyetlere dair ipucu vermişti. Bu girişimler en sonunda kampın rejim karşıtı unsurların kontrolüne geçmesini sağladı ve sonrasında yaşanan süreçler bu zeminde gelişti. ${ }^{37}$

Farklı bir bakış açısı sunan, İslamcı çizgideki gazeteci Ahmet Varol'a göre ise yaşananların yegâne sorumlusu Suriye yönetimiydi. Varol'a göre Suriye'deki "Baas diktası," ülkede yaşayan Filistinli mültecilerden hem kendisine destek verdiklerini yüksek sesle ilan etmelerini, hem de mülteci kamplarında onların himayesine sığınan Suriyeli muhalifleri korumayarak kendilerine teslim etmesini istemişti. Çatışmalı süreci doğuran da rejimin bu yönelimi oldu. Filistinliler, kendilerinden istenenleri yapmadıkları için rejim güçlerinin düzenlediği saldırıların - hava saldırıları dâhil - hedefi oldu. Sürece şahit olan herkes de, saldırıların sebebinin kamptaki muhalif Suriyelilerin orduya teslim edilmemesi olduğunu biliyordu. ${ }^{38}$

37 Reşad Ebu Şever, "Yermuk Kampını Niçin İşgal Ettiler?” (Quds el-Arabi’den çeviren: Hasan Sivri), Medya Şafak, 22 Aralık 2012, http://medyasafak.net/haber/520/yermukkampini-nicin-isgal-ettiler, Son erişim: 27 Mayıs 2019.

38 Ahmet Varol, “Esed’in Hedefindeki Yermük Kamp1,” Haksöz Haber, 20 Aralık 2012, https://www.haksozhaber.net/esedin-hedefindeki-yermuk-kampi-34360h.htm, Son erişim: 27 Mayıs 2019. 
Yermuk'taki çatışmaların başlamasından yaklaşık bir buçuk yıl sonra Carnegie Vakfi'nın web sitesi için bir değerlendirme kaleme alan analist Natasha Hall, Suriyeli isyancıların 2012 sonlarında, o zamana kadar tarafsız bölge kabul edilen Yermuk kampına sığınması sonrasında kampta bulunan Filistinli örgütlerin taraflarını belirlemek zorunda kaldığını ileri sürmektedir. Hall'a göre Hamas, bu çatışmalı süreçte iki ayrı taraftan gelen bask1 karşısında çok zor bir duruma düşmüştü - bu taraflardan biri Müslüman Kardeşler ve Suriye muhalefetine sempati duyan Filistinliler, diğeri ise "velinimetleri olan İran ve Alevi Suriye rejimi" idi. Hamas zamanla, hamileri olan Suriye rejimine sırtını dönüp Mısır ve Katar'a yaklaşmaya başlamıştı. Diğer yandan, Filistin Yönetimi'nin tüm Filistinlilere Suriye çatışmasından uzak durma ve tarafsız kalma çağrısı yapmasına rağmen bu çağrıların beyhude olduğu anlaşılmıştı ve bu durum her şeyden önce, FHKC-GK gibi grupların rejimle işbirliği yapmasından kaynaklıydı. 2011 yılında, FHKC-GK'nın tutumu nedeniyle kampın tarafsızlığını kaybedeceğinden ve çatışmaların içine sürükleneceğinden endişe eden Yermuk sakinleri, örgütün kamptaki merkezlerini ateşe vermişti. 2012 y1lında Liva el-Asife gibi bazı başka Filistinli örgütler de muhaliflerin yanında yer almaya başlamış, liderliğin bu denli parçalanması sonrasında Yermuk tüm taraflardan gelecek saldırılar karşısında korunmasız hale gelmişti. ${ }^{39}$

Bir başka anlatı sunan ABD'li gazeteci Franklin Lamb, süreci daha geniş bölgesel bir bağlam içine yerleştirmektedir. 2007 y1lında Lübnan'daki Nehrü'l-Barid mülteci kampında yaşananları hatırlatan Lamb'e göre, Yermuk'ta da benzer bir süreç yaşanmıştı: 2012 yılı sonlarında yirmi dokuz ayrı ülkeden Selefi güçler Şam'daki Yermuk kampına girdi ve bu unsurlar başta Suudi Arabistan olmak üzere Körfez ülkeleri tarafından silahlandırıld. Bir başka deyişle kampa giren sadece Filistinli olmayan Suriyeli isyanc1lar değil, aynı zamanda Suriyeli de olmayan Esad karşıtı radikallerdi. Diğer yandan Lamb'e göre kampta yaşayan Filistinliler, hegemonik güçlerin (esas olarak ABD ve İsrail'in) olabildiğince fazla sayıda Filistinli mültecinin bölgeden uzaklaşması için çaba gösterdiği kanaatindeydi. Kampın bir çatışma alanına dönüşmesi de bunun sonucuydu. Bir başka deyişle, çeşitli bölgesel ve küresel güçler, 1948 öncesinde yaşadıkları bölgeye geri dönme

39 Natasha Hall, "Palestinian Refugees and the Siege of Yarmouk," Carnegie Endowment for International Peace, 13 Mart 2014, https://carnegieendowment.org/sada/54925, Son erişim: 16 Haziran 2019. 
arzusunu sürdüren Filistinli mültecilerin bu beklentilerinden vazgeçmesi ve yurtlarından daha da uzağa gitmeleri için mülteci kamplarında bu tür çatışmaların yaşanmasını körüklemekteydi. ${ }^{40}$

Lamb, 2013 yılının Ağustos ayında kaleme aldığı bir başka yazıda, Suriye genelindeki mülteci kamplarının yedisinin "yabancı Selefi-cihadçıların postallarının altında" olduğunu yazdı. Lamb'e göre bu "cihadçı hücreler", Filistin kamplarına kendilerine savaşçı temin etmek, kamplarda yaşayan Filistinlileri canlı kalkan olarak kullanmak ve UNRWA tesislerini ele geçirmek için yönelmişti. Söz konusu gruplar, ilk aşamada kamp sakinlerine iyi davranmış, verdikleri dini vaazlarla halkı da etkilemiş, ancak zamanla sigara ya da kadınların örtünmesi gibi konularda baskıcı olmaya başlamış ve en sonunda silah gücüyle kendi otoritelerini kabul ettirmeye çalışmıştı. Yermuk'ta yaşananlar da, Suriye genelindeki kamplarda yaşanan sürecin bir benzeriydi. ${ }^{41}$

Yermuk'ta yaşanan süreçleri, yukarıda sözünü ettiğimiz, açlık ve susuzluktan ölüme varan bir trajedi halini almasından sonra kaleme aldığ yazıda tartışan, Lübnan solunu temsil eden, ancak Hizbullah hareketine (dolayısıyla Beşar Esad yönetimine) yakınlığıyla da bilinen El Ahbar gazetesi genel yayın yönetmeni İbrahim el-Emin ise, yazısına önce bir "özeleştiriyle" başlamaktadır: "Böyle bir konuyu ele almadan önce pişmanlık ifade etmemiz gerekir mi? Öyle olsun, haydi: Bir mülteci kampını kuşatma altına alan suçludur; insanları açlık veya susuzluktan öldüren suçludur; ve böyle bir zulme karşı sesini çıkarmayan suçludur!’42 El-Emin, bu girişin arkasından yazının geri kalan kısmında ise sorumluluğu başka bir tarafa yüklemektedir: bu sorumluluk temel olarak Esad karşıtı Filistinlilere aittir.

Hiç kimsenin kampın tarafsız kalacağını düşünmediğini, fakat "aklı başında hiç kimsenin kampın önemli bir bölümünün silahlarını Suriye'ye karşı

40 Franklin Lamb, "Is Yarmouk Headed for the Same Fate as Nahr el Bared?," Foreign Policy Journal, 22 Aralık 2012, https://www.foreignpolicyjournal.com/2012/12/22/isyarmouk-headed-for-the-same-fate-as-nahr-al-bared/, Son erişim: 10 Haziran 2019.

${ }^{41}$ Franklin Lamb, "Palestinian Refugee Camps in Syria Taken Over by Salafi Jihadists," Foreign Policy Journal, 9 Ağustos 2013, https://www.foreignpolicyjournal. com/2013/08/09/palestinian-refugee-camps-in-syria-taken-over-by-salafi-jihadists/, Son erişim: 10 Haziran 2019.

42 İbrahim el-Emin, "Yermuk: Bir Filistin Sorumluluğu," Medya Şafak, 16 Ocak 2014, http://medyasafak.net/haber/1317/ibrahim-emin--yermuk-kampinda-neler-oluyor, Son erişim: 10 Haziran 2019. El Ahbar sitesinin arşivinin devre dış1 kalması sebebiyle yazının İngilizce orijinaline erişilememektedir. 
kaldıracağını bekleyemeyeceğini” söyleyen İbrahim el-Emin'in kurduğu anlatıya göre kampta önce iç çatışmalar yaşanmış, daha sonra kampta yaşayanların bir bölümü kampı "Suriye devrimi" adına ele geçirmiş ve muhalif Suriyeli silahlı gruplar için bir güvenli bölgeye çevirmişti. Bu durum karşısında Suriye ordusunun kampı bombalaması sonucunda militanlardan ve sivillerden hayatını kaybedenler olmuş ve bunu büyük bir göç dalgası izlemişti. En sonunda Yermuk'ta yalnızca, yeni bir sürgünü reddedenler ile silahlı muhaliffer ve onların aileleri kalmıştı.

Kamptaki en önde gelen grubun "Hamas siyasi büro şefi Halid Meşal'in bir koruması da dâhil olmak üzere Hamas üyeleri tarafından kurulmuş olan Eknaf Beytü'l-Makdis” olduğunu söyleyen El-Emin'e göre Hamas, grubun liderlerinin artık kendi örgütsel yapısının içinde olmadığını ileri sürüyor, ancak eylemlerini kınamayı hâlâ reddediyordu. Bu militanlardan bazıları, kampın dışındaki, hatta Şam kırsalının dışındaki silahlı gruplara da destek sağlamıştı. Kampta yaşananları "yüzde yüz Filistinlilerin sorumluluğu” olarak gören El-Emin'e göre Yermuk’ta Şam rejimine karşı silahlanan kişiler ve Filistin topraklarından çıkarak Şam rejimine karşı savaşmaya giden diğer Filistinliler, ülkelerini işgal eden güce karşı savaşmak yerine Suriye'yi yok etme yoluna girerek, İsrail'e ve ABD'ye hizmet etmiş oluyorlard1. ${ }^{43}$

Buraya kadar olan kısımda sunulan seçili örnekler, özellikle 2012-2014 arasındaki sürece dair çok farklı yorum, anlatı ve değerlendirmelerin olduğunu göstermekle birlikte, ortak bir noktaya da işaret etmektedir: Yermuk krizi, Suriye krizinin doğrudan bir uzantısı olmuştur ve kampın bazı özgün nitelikleri burayı tüm taraflar için önemli kılsa da, Suriye savaşının genel niteliklerinin tümüyle dışında kalan istisnai bir durumdan söz etmek pek mümkün değildir. Ancak - tıpkı makalenin girişinde sözü edilen Neyrab başta olmak üzere diğer mülteci kamplarında olduğu gibi - Yermuk krizinin esas farklarından biri, tüm bu çatışma ve güç mücadelelerinin kurbanlarının, zaten on yıllar önce kendi ülkelerindeki savaş ve işgalin kurbanı olarak yaşadıkları yerleri terk edip, güvenli bir liman olarak Suriye'ye s1ğınmış mülteciler olmasıdır. Kamptaki süreçler, burada yaşayan Filistinlilerin bir bölümünün Suriye içinde başka yerlere gitmesine sebep olurken, bazılarının Suriye'yi de terk ederek ikinci bir sürgün hayatına başlamasına yol açmıştır. Üstelik, her ne kadar 2014 yılının ilk aylarında Yermuk kam-

43 el-Emin, “Yermuk: Bir Filistin Sorumluluğu.", 
pındaki çeşitli Filistinli grupların vardığı uzlaşma sonucunda Suriyeli (ya da genel olarak Filistinli olmayan) isyancılar kampı terk etmiş ve kamp içinde rejim karşıtı olarak yalnızca Eknaf Beytü'l-Makdis gibi gruplar kalmış olsa da kuşatma, çatışmalar ve insani trajedi son bulmamış, 2015 yılının Nisan ayında ise süreç, aşağıda incelenecek olan yeni bir evreye girmiştir.

\section{IŞİD İstilası ve Sonrası}

2015 yılı başlarında Yermuk kampında hâkimiyet farklı unsurlar arasında dağılmıştı. Büyük ölçüde yıkılmış haldeki kampın çoğunluğuna halen Eknaf Beytü'l-Makdis örgütü hâkimdi, ancak kampın kuzey kısmı yeniden FHKC-GK'nın kontrolüne, kuzey ve batı etekleri rejim destekçisi milis gruplarının eline geçmişti; güney ve doğu kısımları "muhalefetin" elinde olarak tanımlanırken, El Kaide örgütünün Suriye kolu Nusra Cephesi de dâhil olmak üzere pek çok silahlı grup da kampta belli tutunma noktaları bulmuştu. ${ }^{44} 1$ Nisan 2015 tarihinde ise, Irak ve Şam İslam Devleti (IŞID, yahut muhtelif adlandırmalarla İD, DAEŞ, DEAŞ) örgütü, stratejik önem atfettiği kampa hücum düzenledi ve kısa süre içinde, güney ve doğu kısımlarını kendi kontrolü altına aldı.

1 Nisan tarihli haberlerde yer alan bilgilere göre, Şam'da bulunan FKÖ yetkilisi Enver Abdülhadi, IŞID'in sabah saatlerinde kampa saldırı düzenlediğini, kampın çoğunun kontrolünü ele geçirdiğini ve çatışmaların sürdüğünü açıklamıştı. Aynı gün, Suriye İnsan Hakları Gözlemevi tarafından da aynı haber duyuruldu. ${ }^{45}$ Yermuk Haber Ajansı'ndan ismi açıklanmayan bir kaynak ise IŞSiD'in Eknaf Beytü'l-Makdis örgütüyle savaşmak üzere kampa girdiğini, kampın güney ve batı kısımlarını ele geçirdiğini açıkladı. Bir kamp sakininin verdiği bilgilere göre ise IŞSiD üyeleri kampa önce roketlerle saldırmış, arkasından baskın düzenlemişti. ${ }^{46}$

44 Nour Samaha, "The Defenders of Yarmouk," Foreign Policy, 4 May1s 2015, https:// foreignpolicy.com/2015/05/04/inside-the-ruins-of-yarmouk-refugee-camp-syria/, Son erişim: 10 Haziran 2019.

45 "ISIS Seizes..."

46 Magdy Samaan, Richard Spencer ve Ruth Sherlock, "Islamic State 'Seizes Most of South Damascus Palestinian Refugee Camp,"” The Telegraph, 1 Nisan 2015, https:// www.telegraph.co.uk/news/worldnews/islamic-state/11509252/Islamic-State-seizesmost-of-south-Damascus-Palestinian-refugee-camp.html, Son erişim: 17 Mayıs 2019. 
Belirtildiği üzere IŞi̇D örgütü Yermuk'a, esas olarak kampın kontrolünü Eknaf Beytü'l-Makdis örgütünden almak için saldırıda bulunmuştu. El Kaide'nin Suriye kolu Nusra Cephesi bu çatışmada tarafsız olduğunu ilan etse de, IŞíD ve Nusra Cephesi'nin bu saldırı ve istila sürecinde koordinasyon içinde hareket ettiği iddiaları da dillendiriliyordu ${ }^{47}$ Diğer yandan IŞID örgütü, kampın kontrolünü önemli ölçüde ele geçirdiği 1 Nisan 2015 tarihinden önce de kampta aktifti. Nitekim bu tarihten önceki aylarda kampta belli bir ağırlık oluşturan örgüt, aktarıldığına göre zamanla kamp içinde kontrol noktaları kurmuş, bir süre sonra sigara içmeyi yasaklamış ve kamptaki kadınlardan tamamen örtünmelerini istemişti. ${ }^{48}$

IŞṠं'in kampa girişi sonrasında Yermuk'tan kaçışlar hızlanırken, Batı Şeria'dan Filistinlilerin oluşturduğu bir heyet durumu değerlendirmek üzere Suriye'ye gitti. Birleşmiş Milletler Güvenlik Konseyi ise kampa insani yardım ulaştırılmasının önündeki engellerin kaldırılması çağrısında bulundu. ${ }^{49}$ Güvenlik Konseyi ayrıca IŞṠD ve El-Nusra'nın Yermuk'taki sivillere karşı işlediği "ağır suçları" kınadı ve bu suçların cezasız kalmaması gerektiğini ifade etti. ${ }^{50}$

Yaklaşık üç yıl boyunca Yermuk kampı, giderek azalan bir nüfusla ve giderek ağırlaşan insani koşullar altında IŞiD örgütünün kontrolü altında kaldı. Kamptaki IŞiD hâkimiyetinin son bulması ise 2018 yılı baharında, hükümet/rejim güçlerinin Şam'ın periferisini tümüyle kontrol altına alma yönündeki geniş çaplı bir operasyonlar dizisinin sonucunda gerçekleşti. Nitekim, Şam'ın dış kısımlarındaki Doğu Guta'nın rejim güçlerinin kontrolüne geçmesinden kısa bir süre sonra Yermuk kampına operasyon için de hazırlıklara başlandı. Halen kampta bulunan az sayıda sivilin tahliyesi için bir süre müzakereler yürütülse de bir sonuç alınamadı. 19 Nisan 2018 günü hükümet güçleri, kampa savaş uçakları ve havan toplarıyla operasyon başlattı. Yermuk kampının güney kısımlarıyla birlikte, yakınlardaki

\footnotetext{
47 "Islamic State-Controlled Yarmouk Refugee Camp..."

48 Samaan vd, "Islamic State Seizes." Buradaki anlatıyla 2012 yılına ilişkin olarak aktardığımız bir başka anlatı arasındaki paralellik dikkat çekmektedir.

49 Charlotte Krol, "Footage Shows Destruction to Yarmouk Refugee Camp in Syria," The Telegraph, 7 Nisan 2015, https:/www.telegraph.co.uk/news/worldnews/islamicstate/11519832/Footage-shows-destruction-to-Yarmouk-refugee-camp-in-Syria.html, Son erişim: 17 Mayıs 2019.

50 "Islamic State-Controlled Yarmouk Refugee Camp..."
} 
Hacerülesved ve Tadamun kasabalarındaki IŞiD ve Nusra unsurları da operasyonun hedefi oldu. ${ }^{51}$

UNRWA'nın değerlendirmelerine göre ordunun operasyonlarının başlamasını takip eden günler içinde Yermuk'ta yaşayan 5 bin civarında Filistinli, yakınlardaki Yelda kasabasına kaçtı. Kuruluşun sözcüsü Gunness'ın E1 Cezire'ye verdiği bilgilere göre o tarih itibariyle kampta yalnızca 1200 kişi kalmıştı. Diğer yandan hava saldırıları başladıktan sonra kampta bulunan tek açık hastane de devre dişı kald1. ${ }^{52}$

Belirtildiği üzere operasyonun hedefi yalnızca IŞiD değil, aynı zamanda Nusra Cephesi, yahut o dönemde aldığı yeni isimle Heyet Tahrirü'ş-Şam (HTŞ) örgütü idi. Operasyonların başlangıcından bir süre sonra, Suriye ve Rusya hükümetlerinin Nusra/HTŞ ile vardığı anlaşma doğrultusunda bu örgütün iki yüz civarında militanı 1 Mayıs 2018 tarihi itibariyle, aileleriyle birlikte Yermuk'tan tahliye edildi ve kuzeydeki İdlib şehrine gitti. Ancak tahliye için kampa giren otobüslerden bazıları da IŞiD örgütünün havan toplu saldırısına uğradi. ${ }^{53}$

Şam periferisindeki başka bölgelerle birlikte, Yermuk mülteci kampının dörtte üçünden fazlasını elinde bulunduran IŞiD'in yenilgiye uğratılması birkaç hafta sürdü. 21 Mayıs 2018 tarihinde Suriye devlet televizyonuna açıklama yapan Suriye ordusu sözcüsü General Ali Meyhub, "Yoğun ve başarılı askeri operasyonlar neticesinde," "Şam ve çevresinin, köy ve kasabalarının tümüyle kontrol altına alındığını" açıkladı. Kontrolün sağlandığı bölgelerden biri de Yermuk kampıydı. Böylelikle kamp, yaklaşık 6 y1l aradan sonra rejim/hükümet güçlerinin kontrolüne geçmiş oldu. Bir önceki gün de Suriye İnsan Hakları Gözlemevi, varılan anlaşma kapsamında IŞSiD'in Yermuk ve Hacerülesved'den tahliye edildiğini duyurmuş, devlet medyası ise örgütle herhangi bir anlaşmaya varılmadığını söylemişti. ${ }^{54} \mathrm{Di}$ -

51 "Assad Forces Target ISIL in Southern Damascus," Al Jazeera, 19 Nisan 2018, https://www.aljazeera.com/news/2018/04/assad-forces-target-isil-southerndamascus-180419180923245.html, Son erişim: 17 Mayıs 2019.

52 Farah Najjar, "Syria's Yarmouk Camp: From a 'War on Stomachs' to 'Annihilation,"” Al Jazeera, 24 Nisan 2018, https://www.aljazeera.com/news/2018/04/syria-yarmoukcamp-war-stomachs-annihilation-180423212111918.html, Son erişim: 17 May1s 2019.

53 Maureen Clare Murphy, “Armed Insurgents Evacuate Yarmouk," Electronic Intifada, 1 Mayıs 2018, https://electronicintifada.net/blogs/maureen-clare-murphy/armed-insurgentsevacuate-yarmouk, Son erişim: 24 Mayıs 2019.

54 "Syria War: Army Takes Full Control of Damascus After Ousting IS," BBC, 21 Mayss 2018, https://www.bbc.com/news/world-middle-east-44198304, Son erişim: 17 Mayıs 2019. 
ğer yandan aynı kuruluşun bildirdiğine göre operasyon sürecine Suriye ordusu öncülük ederken, Rus subayları da danışmanlık yapmış, operasyona yüzlerce Filistinli milis de destek vermişti. ${ }^{55}$

\section{Büyük Çaplı Yıkım ve Yeniden İnşa Arayışları}

Mevcut anlatılar, 2012 sonlarında başlayan iç çatışmalardan 2018 yılının mayıs ayında hükümet/rejim güçlerinin kontrolünü sağlamasına kadar geçen beş buçuk yıllık sürecin sonunda Yermuk kampına hâkim olan manzaranın mutlak bir yıkım manzarası olduğu noktasında ortaklaşmaktadır. Hatta Times of Israel'de yer bulan bir değerlendirme, Yermuk'un genel görünümünü İkinci Dünya Savaş1 esnasında enkaza dönen gettolara benzetmektedir. ${ }^{56}$ UNRWA genel komiseri Pierre Krahenbühl ise, "Yermuk'taki yıkımın boyutu, çatışma bölgelerinde insani çalışmayla geçirdiğim bunca sene içinde gördüğüm çok az şeyle mukayese edilebilir" ifadelerini kullanmıştır. $^{57}$

Mayıs 2018 itibariyle Yermuk'a dair gündeme getirilen başlıca soru, kampa geri dönüp yaşamı sürdürmenin mümkün olup olmadığıydı. Nitekim kamptaki yaşam alanları ve okul ve hastaneler dahil temel önemdeki tesisler, önemli ölçüde tahrip olmuş haldeydi. Eylül ayına gelindiğinde, FKÖ’nün sağladığı finansmanla kampın ana yollarından enkaz kaldırma çalışmaları başladı. Çalışmaların başında bulunan Mahmud Halid tarafından belirtildiğine göre, o tarih itibariyle kamptaki binaların yüzde 40'1 ciddi oranda hasarl1 durumdayd1. ${ }^{58}$

Kasım ayı başlarında Suriye Dışişleri Bakanı Yardımcısı Faysal Mikdat, Lübnan merkezli El-Menar televizyonuna verdiği bir röportajda, tüm Filistinli mültecilerin Yermuk kampına geri dönmesinin planlandığını ifade etti, ancak bunun ne zaman ve nasıl olacağına dair bir bilgi vermedi. Aynı

55 "Palestinian Camp Yarmouk..."

56 "Palestinian Camp Yarmouk..."

57 Hwaida Saad ve Megan Specia, "Memories Lost and Futures on Hold: A Look Inside a Camp for Syria's Displaced," New York Times, 11 Nisan 2018, https://www.nytimes. com/2018/07/11/world/middleeast/syria-war-displaced-yarmouk.html, Son erişim: 17 Mayıs 2019.

58 Ayşe Nur Dok, "How Displaced Palestinians Struggle to Live in War-Torn Syria," TRT World, 8 Kasim 2018, https://www.trtworld.com/middle-east/how-displacedpalestinians-struggle-to-live-in-war-torn-syria-21506, Son erişim: 24 Mayıs 2019. 
tarihlerde UNRWA yetkilileri tarafindan ise, kampta bulunan ve ajansa ait olan on altı okul da dâhil olmak üzere toplam yirmi üç bina ve tesisin zarar gördüğü, ancak rejim tarafından Filistinlilerin kampa dönmesine resmen izin verilinceye kadar yeniden inşa faaliyetlerine başlamayacakları söylendi. ${ }^{59}$ Hükümet yetkilileri tarafından dönüşlere izin verileceği resmen açıklandığı zaman ise hem UNRWA hem de Londra merkezli bir oluşum olan Suriye'deki Filistinliler için Eylem Grubu (Action Group for Palestinians in Syria-ACPS) açıklamayı memnuniyetle karşıladı ve kampın yaşanılabilir kılınması için gerekli tedariklerin sağlanmasını talep etti. Filistin Yönetimi'ne ve FKÖ’ye de bu yönde destek çağrıları yapıld1 $1{ }^{60} \mathrm{Bu}$ makalenin kaleme alındığı tarih itibariyle gerek Yermuk kampının yeniden inşası faaliyetleri, gerekse de kampa dönüşler, ağır bir tempoyla da olsa devam etmekteydi.

\section{Sonuç}

Giriş kısmında da belirtildiği üzere, Suriye savaşının yıkıcı etkilerini yaşayan tek Filistin mülteci kampı Yermuk değildi. UNRWA tahminlerine göre, 2011 yılından itibaren toplam 120 bin Filistinli Suriye'yi terk ederek komşu veya daha uzak ülkelere gitti; ülkedeki toplam Filistinli nüfusun yarıdan fazlası ise Suriye içinde yer değiştirdi. Diğer yandan, Suriye'deki Filistinliler için Eylem Grubu'nun verdiği bilgilere göre 2011'de çatışmalı sürecin başlamasından itibaren dört bine yakın Filistinli mülteci hayatını kaybetti; iki bine yakın Filistinli tutukland1, 315 'i ise kayboldu. ${ }^{61}$

Bu bağlamda, 2012-2018 yılları arasında Yermuk kampında yaşananlar öncelikle, Suriye genelindeki Filistin mülteci kamplarının ve genel olarak Suriye'de yaşayan Filistinli mültecilerin savaş sürecinden etkilenmesi aç1sindan, yalıtık olmayan bir örnek niteliğindedir. Diğer kamplara nazaran Yermuk'un daha fazla öne çıkmasının sebepleri ise birinci olarak bu kampın diğerlerinden daha büyük olması, ikinci olarak buradaki çatışma ve yıkım sürecinin diğer kamplardakinden çok daha büyük ölçekli olmasıdır.

\footnotetext{
59 Ayşe Nur Dok, "How Displaced Palestinians..."

60 Maureen Clare Murphy, "Armed Insurgents Evacuate Yarmouk"

${ }_{61}$ "Total victims according to incident place," Action Group For Palestinians in Syria web sitesi, http://www.actionpal.org.uk/en/statistic-and-charts/3/10/col/total-victimsaccording-to-incident-place, Son erişim: 14 Haziran 2019.
} 
Özellikle 2012 sonunda başlayan kuşatma süreci Yermuk kampı sorununun ciddi bir gündem haline gelmesi sonucunu getirmiştir.

İkinci olarak Yermuk'ta yaşanan süreçler, genel olarak Suriye savaşında yaşanan süreçlerden de bağımsız değildir. Kampın pek çok defa, çoktaraflı bir şiddetin hedefi olmasının esas sebebi başkentin merkezine ve başkanlık sarayına oldukça yakın ve stratejik bir konumda olmasıdır. Çatışmanın tarafları, Suriye çatışmasının ana taraflarıyla paralel veya aynı olup, bu kampın bir Filistin mülteci kampı olması çatışmaya bu anlamda özgün bir nitelik getirmemiştir. Diğer yandan kampın hukuki durumundan ötürü kuşatma altına alınması hem "teknik" bir farklılık, hem de çok özgün insani sonuçlar üretmiş olsa da, kuşatma yöntemi, Suriye savaşı boyunca farklı taraflarca farklı yerlerde kullanılmıştır. Rejim karşııı unsurların İdlib'in kontrolünü ele geçirdikten sonra kendilerine direnç gösteren Şii kasabaları Fua ve Kefraya'da üç yıl boyunca devam ettirdiği kuşatma bunun bir örneğidir.

Tüm bunlarla birlikte Yermuk'un bir Filistin mülteci kampı olması, siyasi, sosyolojik ve insani açıdan, Suriye'nin diğer yerlerinde yaşananlardan çok farklı bir sonucu da beraberinde getirmiştir: Yüz binden fazla kişi, "başkalarının ülkesinde" gelişen ve çoğunlukla taraf olmadıkları bir çatışmanın kurbanı olmuş ve - eğer hayatta kalabilmişlerse - on y1llar sonra ikinci bir sürgünü yaşamışlardır. Bu durum bazı açılardan, makalenin başlangıç kısımlarında değindiğimiz, Kara Eylül ve Sabra-Şatila katliamı gibi Araplar arası çatışmalar ve bunların sonuçlarıyla paralellik taşımaktadır. Ancak geçmişte Ürdün ve Lübnan'da yaşananlardan farklı olarak, Yermuk'ta yaşayanların özel olarak Filistinli olmaları sebebiyle hedef olduklarını düşünmemiz için yeterli bir sebep yoktur. Yine de, Franklin Lamb'den yaptığımız alıntıda sözü edilen, mülteci kamplarını boşaltma ve geri dönüş fikrini imkânsızlaştırma amacıyla bir tasarımın hayata geçirildiği iddiası üzerinde düşünmeye değer görünmektedir.

Hiç kuşku yok ki gelecekte Suriye savaşıyla ilgili çok yoğun bir literatür gelişecek, Suriye'deki Filistinlilerin bu süreçten ne şekilde etkilendikleri de bu literatürün üzerinde durduğu sorulardan biri olacaktır. Bu makaleyle, yeni yeni oluşmakta olan bu birikime mütevazı bir katkı sağlanmış olunduğu umulmaktadır. 


\section{Kaynakça}

Al-Hardan, Anaheed. "A Year On: The Palestinians in Syria," Syrian Studies Association Bulletin 17, say1 1 (2012): 1-7.

Al-Hardan, Anaheed. "The Right of Return in Syria: Building a Culture of Return, Mobilizing Memories for the Return," Journal of Palestine Studies 41, say1 2 (Kış 2012): 62-79.

Ali, Zarefa Akram. A Narration Without an End: Palestine and the Continuning Nakba, Yüksek Lisans Tezi, Birzeit Üniversitesi (Danışman: Dr. Rana Barakat), 2012.

Bitar, Nidal. "Yarmouk Refugee Camp and the Syrian Uprising: A View from within,” Journal of Palestine Studies 43, say1 1 (Güz 2013): 61-78.

Bocco, Riccardo. "UNRWA and the Palestinian Refugees: A History Within History," Refugee Survey Quarterly 28, say1 2-3 (Ocak 2009): 229-252.

Brand, Laurie. "Palestinians in Syria: The Politics of Integration," Middle East Journal 42, say1 4 (Kış 1988): 621-637.

Chesnot, Christian ve Lama, Joséphine Lama, Filistinliler - 1948-1998 Fedai Nesli: Silahlı Mücadeleden Özerkliğe, çev. Sezai Arusoğlu, Ankara: Doruk Yayımc1lık, 2003.

Cleveland, William L. A History of the Modern Middle East, Üçüncü Bask1, Colorado ve Oxford: Westview Press, 2004.

Rolland, John C. (haz.) Lebanon: Current Issues and Background, New York: Nova Science Publishers, 2003.

Tessler, Mark. A History of the Israeli-Palestinian Conflict, İkinci Bask1, Bloomington ve Indianapolis: Indiana University Press, 2009.

Vallaud, Pierre. Le Liban Au Bout Du Fusil, Paris: Librairie Hachette, 1976.

\section{Internet Kaynakları}

Suriye Arap Cumhuriyeti Merkezi İstatistik Bürosu web sitesi, 19 Eylül 2019, http://cbssyr.sy/yearbook/2012/Data-Chapter2/TAB-12-2-2012.pdf, http://cbssyr.sy/yearbook/2013/Data-Chapter2/TAB-12-2-2013.pdf, http://cbssyr.sy/yearbook/2017/Data-Chapter2/TAB-14-2-2017.pdf. 
“Assad Forces Target ISIL in Southern Damascus," Al Jazeera, 19 Nisan 2018, https://www.aljazeera.com/news/2018/04/assad-forces-target-isilsouthern-damascus-180419180923245. html, Son erişim 17 Mayıs 2019.

"Hamas Denies Supporting Militant Groups in Syria," Middle East Monitor, 19 Nisan 2015, https://www.middleeastmonitor.com/20150419-hamasdenies-supporting-militant-groups-in-syria/, Son erişim: 10 Haziran 2019.

"ISIS Seizes Most of Yarmouk Refugee Camp in Damascus: PLO," Daily Star, 1 Nisan 2015, http://www.dailystar.com.lb/News/Middle-East/2015/Apr-01/292956isis-seizes-most-of-yarmouk-refugee-camp-in-damascus-plo.ashx, Son erişim: 27 Mayıs 2019.

"Islamic State-Controlled Yarmouk Refugee Camp Conditions Beyond Inhumane," The Telegraph, 7 Nisan 2015, https://www.telegraph.co.uk/news/worldnews/islamic-state/11519106/ Islamic-State-controlled-Yarmouk-refugee-camp-conditions-beyondinhumane.html, Son erişim: 17 Nisan 2019.

"Palestinian Camp Yarmouk, Back in Assad Hands, Gutted by Years of War," Times of Israel, 21 Mayis 2018, https://www.timesofisrael.com/palestinian-camp-yarmouk-back-inassad-hands-gutted-by-years-of-war/, Son erişim: 24 Mayıs 2019.

"Syria is a Battle for Palestine," Islam Times English, t.y., https://www.islamtimes.org/en/interview/251081/syria-is-a-battle-forpalestine, Son erişim: 10 Haziran 2019.

"Syria War: Army Takes Full Control of Damascus After Ousting IS," $B B C, 21$ Mayıs 2018, https:/www.bbc.com/news/world-middle-east-44198304, Son erişim: 17 May1s 2019.

"Total Victims According to Incident Place," Action Group For Palestinians in Syria web sitesi, http://www.actionpal.org.uk/en/statistic-and-charts/3/10/col/totalvictims-according-to-incident-place, Son erişim: 14 Haziran 2019.

"UNRWA Condemns the Killing of 10 Civilians in the Palestine Refugee Camp of Neirab in Aleppo," UNRWA,

https://reliefweb.int/report/syrian-arab-republic/unrwa-condemnskilling-10-civilians-palestine-refugee-camp-neirab-aleppo, Son erişim: 16 May1s 2019. 
"Where We Work-Syria," UNRWA, https://www.unrwa.org/where-we-work/syria, Son erişim: 19 Eylül 2019.

“Where We Work-Syria-Yarmouk (Unofficial Camp)," UNRWA, https://www.unrwa.org/where-we-work/syria/yarmouk-unofficialcamp, Son erişim: 20 Eylül 2019.

Dok, Ayşe Nur. "How Displaced Palestinians Struggle to Live in War-Torn Syria," TRT World, 8 Kasim 2018, https://www.trtworld.com/middle-east/how-displaced-palestiniansstruggle-to-live-in-war-torn-syria-21506, Son erişim: 24 Mayıs 2019.

Ebu Şever, Reşad. "Yermuk Kampını Niçin İşgal Ettiler?" (Quds elArabi'den çeviren: Hasan Sivri), Medya Şafak, 22 Aralık 2012, http://medyasafak.net/haber/520/yermuk-kampini-nicin-isgal-ettiler, Son erişim: 27 Mayıs 2019.

El-Emin, İbrahim. "Yermuk: Bir Filistin Sorumluluğu," Medya Şafak, 16 Ocak 2014, http://medyasafak.net/haber/1317/ibrahim-emin--yermuk-kampindaneler-oluyor, Son erişim: 10 Haziran 2019.

Hall, Natasha. "Palestinian Refugees and the Siege of Yarmouk," Carnegie Endowment for International Peace, 13 Mart 2014, https://carnegieendowment.org/sada/54925, Son erişim: 16 Haziran 2019.

Karouny, Mariam. "Syrian Rebels Take Control of Damascus Palestinian Camp," Reuters, 17 Aralık 2012, https://www.reuters.com/article/us-syria-crisis/syrian-rebels-takecontrol-of-damascus-palestinian-camp-idUSBRE8AJ1FK20121217, Son erişim: 10 Haziran 2019.

Krahenbühl, Pierre. "Palestine Refugees in Syria: A Tale of Devastation and Courage," UNRWA, 14 Mart 2019, https://reliefweb.int/report/syrian-arab-republic/palestine-refugeessyria-tale-devastation-and-courage, Son erişim: 24 Mayıs 2019.

Krol, Charlotte. "Footage Shows Destruction to Yarmouk Refugee Camp in Syria," The Telegraph, 7 Nisan 2015, https://www.telegraph.co.uk/news/worldnews/islamic-state/11519832/ Footage-shows-destruction-to-Yarmouk-refugee-camp-in-Syria.html, Son erişim: 17 Mayıs 2019. 
Lamb, Franklin. "Is Yarmouk Headed for the Same Fate as Nahr el Bared?," Foreign Policy Journal, 22 Aralık 2012, https:/www.foreignpolicyjournal.com/2012/12/22/is-yarmoukheaded-for-the-same-fate-as-nahr-al-bared/, Son erişim: 10 Haziran 2019.

Lamb, Franklin. "Palestinian Refugee Camps in Syria Taken Over by Salafi Jihadists," Foreign Policy Journal, 9 Ağustos 2013, https://www.foreignpolicyjournal.com/2013/08/09/palestinianrefugee-camps-in-syria-taken-over-by-salafi-jihadists/, Son erişim: 10 Haziran 2019.

Loveluck, Louisa; Samaan, Magdy ve Sherlock, Ruth. "Inside the Living Hell of Yarmouk," The Telegraph, 7 Nisan 2015, https:/www.telegraph.co.uk/news/worldnews/islamic-state/11520845/ Inside-the-living-hell-of-Yarmouk.html, Son erişim:17 Mayıs 2019.

Murphy, Maureen Clare. "Armed Insurgents Evacuate Yarmouk," Electronic Intifada, 1 Mayıs 2018, https://electronicintifada.net/blogs/maureen-clare-murphy/armedinsurgents-evacuate-yarmouk, Son erişim: 24 Mayıs 2018.

Murphy, Maureen Clare. "Syrian Government Approves Return to Yarmouk", Electronic Intifada, 10 Kasım 2018, https://electronicintifada.net/blogs/maureen-clare-murphy/syriangovernment-approves-return-yarmouk, Son erişim: 24 Mayıs 2019.

Najjar, Farah. "Syria's Yarmouk camp: From a 'War on Stomachs' to "Annihilation," Al Jazeera, 24 Nisan 2018, https://www.aljazeera.com/news/2018/04/syria-yarmouk-camp-warstomachs-annihilation-180423212111918.html, Son erişim: 17 Mayıs 2019.

Saad, Hwaida ve Specia, Megan. "Memories Lost and Futures on Hold: A Look Inside a Camp for Syria's Displaced," New York Times, 11 Nisan 2018, https:/www.nytimes.com/2018/07/11/world/middleeast/syria-wardisplaced-yarmouk.html, Son erişim: 17 Mayıs 2019.

Samaan, Magdy; Spencer, Richard ve Sherlock, Ruth. "Islamic State 'Seizes Most of South Damascus Palestinian Refugee Camp," The Telegraph, 1 Nisan 2015, https://www.telegraph.co.uk/news/worldnews/islamic-state/11509252/ Islamic-State-seizes-most-of-south-Damascus-Palestinian-refugeecamp.html, Son erişim: 17 Mayıs 2019. 
Samaha, Nour. "The Defenders of Yarmouk," Foreign Policy, 4 Mayıs 2015,

https://foreignpolicy.com/2015/05/04/inside-the-ruins-of-yarmoukrefugee-camp-syria/, Son erişim: 10 Haziran 2019.

Sanchez, Raf. "Palestinian Refugee Camp in Syria Turns 'Unimaginably Brutal' as Assad Regime Drives Isil out of Yarmouk," The Telegraph, 26 Nisan 2018,

https://www.telegraph.co.uk/news/2018/04/26/palestinian-refugeecamp-syria-turns-unimaginably-brutal-assad/, Son erişim: 17 Mayıs 2019.

Varol, Ahmet. "Esed'in Hedefindeki Yermük Kamp1," Haksöz Haber, 20 Aralik 2012,

https://www.haksozhaber.net/esedin-hedefindeki-yermuk-kampi34360h.htm, Son erişim: 27 Mayıs 2019. 